\title{
The polemical practice in ancient Epicureanism*
}

\author{
M. M. Shakhnovich \\ St. Petersburg State University, \\ 7-9, Universitetskaya nab., St. Petersburg, 199034, Russian Federation
}

For citation: Shakhnovich M.M. The polemical practice in ancient Epicureanism. Vestnik of Saint Petersburg University. Philosophy and Conflict Studies, 2019, vol. 35, issue 3, pp. 461-471.

https://doi.org/10.21638/spbu17.2019.306

The article explores the presentation methods of a philosophical doctrine in Greek and Roman Epicureanism; it is shown that for the ancient, middle, and Roman Epicureans a controversy with representatives of other philosophical schools was a typical way of presenting their own views. The polemical practice, in which the basic principles of Epicureanism were expounded through the criticism of other philosophical systems, first of all, Academics and Stoics, was considered not only as the preferred way of presenting the own doctrine, but also as the most convenient rhetorical device, which had, among other things, didactic significance. The founder of the school, Epicurus, often included in his texts the terms used in other philosophical schools, giving them a different, often opposite, content. While presenting his teaching in the treatise "On Nature" or in letters to his followers, Epicurus pushed off the opinions of Democritus, Plato, and the Stoics, but resorted mainly to implicit criticism of his opponents, often without naming them by name. His closest students and later followers - Metrodorus, Hermarchus, Colotes, Philodemus, Lucretius, Diogenes of Oenoanda - continuing the controversy with the Academics and the Stoics, more frankly expressed their indignation about the "falsely understood Epicureanism" or erroneous opinions. In their writings, satirical techniques and angry denunciations were often used to criticize opponents. The focus of the article is on the controversy of Epicurus with Plato; the interpretation of the concept of "anticipation" in Epicurus and the Stoics, the polemic controversies and the use of the principle of "refraining from judgment", drawn from the Stoics, to criticize Academics. In addition, the article analyzes the rhetorical tricks of Philodemus, who believed that frank speech is not only the best way to heal the soul, but also a method of philosophical controversy.

Keywords: Epicurus, Epicureanism, Colotes, Philodemus, Roman Epicureanism, Stoicism, Academic Scepticism, polemic method.

Usually, Stoicism and Epicureanism are considered separately as independent philosophical schools, however, the common cultural and historical context of their appearance and development is traditionally indicated. The way of presenting one's own views through the criticism of opponents distinguished the works of Epicureans and the Stoics and was used by them as the most convenient rhetorical device. This technique also had a didactic value and was cultivated within the framework of both schools, and their founders set the tone.

* The article was written with the support of the RFBR grant No. 18-011-01123 "The Problem of Connecting Morality and Religion in Epicurean and Stoic Philosophy: A Comparative Analysis of the Controversial Discourse".

(c) Санкт-Петербургский государственный университет, 2019 
There is an opinion that Epicurus not only rejected the teachings of all other philosophers, but was himself ignorant in the field of philosophy. This is one of the many legends that have accompanied Epicureanism throughout the centuries of the history of this school. Epicurus was well aware of the philosophical concepts of his predecessors and contemporaries. For example, in his mature years he wrote a special work "Against Theophrastus", and his essay "On Nature" testifies to the knowledge of Aristotle's early esoteric writings. Diogenes Laertius reported that among the ancient philosophers the closest to Epicurus were Anaxagoras and Archelaus, the teacher of Socrates (DL X, 12). According to Cicero, the philosophy of Epicurus fully grew out of the teachings of Democritus (ND I, 73). The most interesting in this regard is the attitude of Epicurus to Plato.

It is well known that Epicurus argued with Plato. The main work of Epicurus "On Nature", was written in a controversy against determinism, contained a criticism of early natural philosophers, early atomists, Stoics, Plato and Aristotle. Out of twenty-two known works by the favorite student of Epicurus, Metrodorus, eight (only judging by the names) were written in the polemical manner: "Against the healers", "Against Timocrates", "Against the dialecticians", "Against the Sophists", "Against Democritus", "Against Plato's 'Gorgias"” (criticism of the ideas about the posthumous judgement for corporeal souls), "Against Plato's 'Euthyphro"' (on internal and external piety). Hermarchus wrote an essay "Against Empedocles", and Polyaenus "Against Aristotle". Colotes wrote "Against Plato's 'Euthydemus"' (on the art of dispute) and "Against Plato's 'Lysis"' (about friendship). Epicureans Zeno of Sidon, Demetrius of Lakonia, Lucretius, Philodemus, Diogenes of Oenoanda, all of them in their writings argued with their opponents, defending and attacking, and sometimes did not hesitate in expressions, calling opponents 'charlatans', 'deceivers' and even 'madmen'.

Epicurus was an opponent of Plato in the field of metaphysics and epistemology, in the sphere of relations to the state and politics, religion and art. Excerpts from the fundamental work of Epicurus "On Nature", found in Herculaneum papyri, show that he rejected Plato's cosmology, the doctrine of the world soul, astrology, according to which stars and planets are divine beings. Eusebius wrote: "What he can have in common with Plato is he, who removed from his field of vision the divine nature, cut off the soul's hope for a new appearance in the future" (Praep. Ev. XV, 5, 3). However, Epicurus and his followers knew perfectly well the works of Plato. They rejected Platonism by no means blindly or absolutely. Criticizing Plato, they used his vocabulary and images, filling them with other content. Diogenes Laertius, enumerating the nicknames given by Epicurus to the various philosophers, reported that Epicurus called Plato "golden" (DL X, 8), that is, "divine". It is known that Plato speaks about the role of the philosopher in the ideal state, he writes, that God fashioned philosophers able to rule, and mixed them in birth with gold, and therefore they are most valuable (Resp. 415 a). Last century scholar Frederick Solmsen believed that Epicurus, not only argued with the ideas expressed by Plato, but consciously built his philosophical system as anti-academic. He attributed the anti-Platonian passages of Lucretius to Epicurus himself, wanting to prove that the latter not only argued with the ideas expressed in "Timaeus", but consciously built his philosophical system as directed against Platonism [1, p. 11; 2, p. 37].

Epicurus and his followers subjected Plato's notions and images to rethinking, inherently criticized. For example, likening to God was the ethical ideal of Platonism. The "Phaedo" tells about the soul, which best followed God and became like him (Ph. 248). 
Being outside human vanity and facing the divine, it turns out that the perfect man is a wise philosopher. In Epicureanism, this view was rethought. The use and rethinking of the Platonic notions by the Epicureans is also confirmed by the reference to Epicurus in the comments to the "Phaedrus". The terminological and figurative parallels noted in the texts of Plato and Epicurus, as well as Plato and the Epicureans, indicate not so much substantive, but formal borrowing. This reception was a means of controversy. For example, for Platonists, friendship was a means of building an ideal state. Epicurus valued friendship in itself, as something good, bringing pleasure. A peculiar rethinking of Plato's plots can be found in the poem "On the Nature of Things" by Lucretius. The third book of Lucretius' poem is polemical and directed mainly against the arguments of the immortality of the soul set forth in "Phaedo" (NR III, 440; 960-967; 1003-1010), but in the description of the eternal world of the gods in "Epicurus Praise" (NR III, 1-30) traced the influence of the Platonic notion of souls who saw true being (Phdr. 249a-d).

Epicurus denied any outside intervention in the process of the emergence of the world, opposing theocosmogony and philosophical theories about the prime mover and the demiurge. Velleius, the Epicurean, in Cicero's treatise "On the Nature of Gods", evaluating the significance for man of the cosmogonic ideas of Epicurus, used the expression out of the legal practice to characterize the liberation of man from the slave state (ND I, $\mathrm{XX}, 56$ ). Arguing with his opponents, Velleius expounded the essence of Epicurus's cosmogony as follows: “...the world was created naturally, without the need for a craftsman's role, and the process which in your view cannot be put in train without the skillful touches of a god is so straightforward that nature has created, is now creating, and will continue to create innumerable worlds...It is in this boundless extent of breadth, length, and height, then, that innumerable atoms in infinite quantity flit around. There is space between them, yet they latch on to each other. In gripping each other they form a chain, as a result of which are fashioned the shapes and forms of thing which you Stoics believe cannot be created without bellows and anvils"(ND I, XX, 53-54) [3, p. 21-22].

By eliminating faith in the divine creator, atomists opened the way to the creation of cosmogonic hypotheses based on the atomistic teaching. Epicurus, arguing with Leucippus and Democritus, pointed out that for the emergence of the world is not enough just clusters of atoms or a certain vortex, which came into motion by necessity, and that the growth of the world is impossible until it collides with another world. Epicurus put forward the principle of not only self-movement, but also self-organization of matter: "It arises when certain suitable seeds rush in from a single world or intermundium, or from several, and undergo gradual additions or articulations or changes of place, it may be, and waterings from appropriate sources, until they are matured and firmly settled in so far as the foundations laid can receive them"(DL X, 89) [4, p. 617].

Epicurus recognized the intrinsic activity of matter, the emergence of a qualitatively new, complete and perfect, from the nonexistent and disorderly. He acted as the successor of the ancient cosmogonic tradition, according to which order arises from disorder, cosmos from chaos, but this process is carried out according to Epicurus, spontaneously and without the intervention of external forces. Developing the atomic doctrine, Epicurus created the theory of spontaneous deviation of an atom from a straight line (parenklisis; in Lucretius, clinamen). This doctrine defined the source of motion as immanently inherent in matter itself, expanded the concept of the atom as the root cause, served as the theoretical basis for the anti-religious moralizing of Epicurus. Lactantius in the work "Divine 
Institutes" wrote that Epicurus concluded that there is no providence, that there is no expediency in what is happening.

It is known that the ancient Greeks had the word pronoia, meaning foresight, providence, divine care for people. It is found in Sophocles and Herodotus, it was inscribed on the statue of Athena Pronaia at Delphi. The concept of "divine providence" is found in Plato. The Stoics regarded Logos as providence and believed that divine predestination prevails in the world (ND I, VIII, 73; II, XIX, 73). Epictetus criticized Epicurus for seeing blind chance instead of providence. This word is used in the treatise "Against the Colotes" by Plutarch in connection with the criticism of Epicurean wickedness (see also: Def. Orac. 19). The denial of divine providence by ancient atomists, the proclamation of the idea of a world not ruled by gods, were of fundamental importance. Lactantius wrote that if God exists, then he is the discerner, and if Epicurus denies providence, by that he also denies that God exists. Johann Trithemius, German theologian of $15^{\text {th }}$ cent., in his treatise "On Providence" stated: "Who denies the providence, denies the creature of God and, in fact, says nothing but the fact that there is no God... If God does not bake, consciously and unconsciously, about man, then no reason for the existence of religion, for there is no hope of salvation" [5, p. 302].

According to Epicurus, isolated ideas arise on the basis of sensory perceptions, and on their basis, in their turn appear general concepts or concepts, called Epicurus prolepseis. According to Diogenes Laertius, the concepts of the Epicureans were closely related to the sensual experience and arose from it: "By preconception they mean a sort of apprehension or a right opinion or notion, or universal idea stored in the mind; that is, a recollection of an external object often presented" (DL X, 33) [4, p.563]. Epicurus used this term to define a sensory image stored in memory, as opposed to a new sensory impression. Attempts to present the Epicurean prolepsis as an innate idea, as an a priori knowledge are based on the fact that Cicero mixed the meaning of this term in the Stoics and Epicureans. Epicurus, according to Cicero, calls prolepsis "the concept of an object previously grasped by the mind, without which it can be understood, investigated, or discussed" (ND XVI, 43) [3, p.18]. The word prolepsis means "premonition", "preconception", but as a philosophical term among the Stoics and the Epicureans, it had a different meaning: for the Stoics, this is a primary general concept that comes into effect only in connection with experience, but innate (DL VII, 54). While the Epicureans have an empirical, natural, general concept, obtained as "the memory of what often appeared to us from the outside... We should never have started an investigation, unless we had known what it was that were in search of. For example: The object standing yonder is a horse or a cow. Before making this judgement, we must at some time or other have known by preconception the shape of a horse or a cow. We should not have given anything a name, if we had not first learnt its form by way of preconception. It follows, then, that preconceptions are clear. The object of a judgement is derived from something previously clear, by reference to which we frame the proposition" (DL X, 33) [4, p. 563].

The doctrine of prolepsis was very important for the philosophy of religion of Epicurus, because it made it possible to explain the existence of ideas about gods among people. Epicurus distinguished "preconceptions" from false knowledge. In a letter to Menoeceus, he wrote: "For the utterances of the multitude about the gods are not true preconceptions but false assumptions; hence it is that the greatest evils happen to the wicked and the greatest blessings happen to the good from the hand of the gods" (DL X, 123) [6, p. 649]. The 
only thing that limits the content of the concept of prolepsis in Epicurus is the limit of our perception [7, p. 175-215].

A special role in the genesis of superstitious fears, according to Epicurus, was played by the worship of celestial bodies, which was supported by the Pythagoreans, Plato and the Stoics, who considered them living beings. Epicurus argued that the greatest fear among people is caused by faith in the sky, inhabited by immortal gods. Therefore, trying to free people from the fear of him, he sought to find a natural explanation for the movement of celestial bodies, eclipses, sunrise and sunset, etc. In his opinion, one cannot destroy fear about the most important things without knowing the nature of the universe, but suspecting the truth in something that is told in myths (Principal Doctrines, XII).

Aetius reported that Epicurus, following Democritus, considered the soul mortal (Aec. IV, 7, 4). The soul, he believed, consists of the most subtle atoms, smooth and round, scattered throughout the human body: it lacks the ability to feel if there is no soul, just as the soul cannot exist without a body. They are inseparable, for "on the departure of the soul the body loses sentience" (DL X, 65) [4, p. 615].

A pupil of Epicurus, Hermarchus criticized Pythagoras, Plato and Empedocles for their ideas about the gods [8, fr. 27-34], and according to Cicero's remark, he believed that the gods are no different from humans (ND I, 33.93). Philodemus discussing, whether the gods can breathe and speak (De piet. Col. 13.36-14.6), arguing with opponents of the Epicurean doctrine of the gods, referred to Hermarchus. Plutarch in the essay "On the Obsolescence of the Oracles" (420 a - c) meant Hermarchus and his treatise "Against Empedocles", when he said that the Epicureans denied the possibility of the existence of the demigods (demons), whom Empedocles taught to exist [7, p. 134-135], because from Epicurean point of view, only serene and blissful beings can be eternal, otherwise they will be destroyed.

Colotes, one of the closest students of Epicurus, was a great polemicist, and all the writings of this philosopher known to us were written in a critical manner. There are two groups of sources testifying to the creative heritage of Colotes: the first group is the texts of Colotes himself, which have come down to us thanks to the opening of the Herculaneum library. These are small and damaged fragments of polemical writings: "Against Plato's 'Lysis"' and "Against Plato's 'Euthydemus"' (papyri 208 and 1032 respectively, first published by W. Crönert [6]).

The Herculaneum papyrus 208 contains two fragments from the essay "Against Plato's 'Lysis"'. The first is about the poet and poetry, which indicates that Colotes, after his teacher, speaks out against poetry that has no ethical significance and educational purpose. The second is about wisdom as a way to achieve happiness. Both fragments are very characteristic of the rhetorical manner of the Epicureans: in both cases, the words of Socrates from Plato's dialogue are used critically as material for the presentation of Epicurus' point of view. There is lemma and then follows a critical comment on it.

In the same manner, the surviving text from the work "Against Plato's 'Euthydemus"' in the Herculaneum papyrus 1032 is written. The content of this papyrus, which represents the earliest evidence of the controversy of the Epicureans and the representatives of the New Academy, overlaps in part with the polemic passages of Colotes against Arcesilaus, which Plutarch leads in his essay "Reply to Colotes". Thanks to Proclus' commentaries on Plato's "Republic" and Macrobius' commentaries on Cicero's "The Dream of Scipio", we know, that Colotes was the author of an essay in which he criticized the famous tale of 
Socrates about Er, native of Pamphylia, from the tenth book of Plato's "Republic". Conventionally, this essay by Colotes is called "Against the myth in Plato". A number of researchers, in particular W.H.Stahl [9, p.23-39] and M.Armisen-Marchetti, who published the commentaries of Macrobius [10, p.liv-lxvii], and E. Kechagia [11, p.68-69] as well, believe that Proclus' and Macrobius' information about Colotes' work was drawn from Porphyry's "Commentaries on the 'Republic", and neither Proclus nor Macrobius did not even see Colotes' very story, which deals with the posthumous travel of Er and criticizes of the doctrine of afterlife reward.

A special place among the sources on Colotes is occupied by two treatises by Plutarch "Reply to Colotes in Defense of the Other Philosophers" and "That Epicurus Actually Makes a Pleasant Life Impossible". The very name of one of these treatises points to a controversy with Colotes' essay "That it is impossible even to live according to the philosophers". It is interesting, that this work of Colotes is addressed not to the students of the Epicurean school, but to the young listeners of the New Academy and is directed against the philosophical scepticism of Arcesilaus, who headed it. In it, Colotes, considering the question of the criterion of truth, criticized the doubts of many philosophers about the authenticity of sensations. First, Colotes criticizes Democritus, and then turns sequentially to the teachings of Parmenides, Empedocles, Socrates, Melissus, Plato and Stilpo, as well as two contemporary philosophical schools of Cyrenaics and Academics (led by Arcesilaus). He does not name them, but it clearly follows from the text of the book, and Plutarch draws attention to this.

The general accusation made by Colotes against these philosophers is as follows: their teachings make it impossible for any person to communicate with the outside world and, consequently, human existence itself. Colotes believes that he, who denies the truth of sensory perception cannot say with confidence about himself whether he is dead or alive. The main object of criticism of Colotes is the principle of "refraining from judgment" (epoche) of Arcesilaus, which Colotes refutes on the basis of the principle of "inactivity" (apraxia). Interestingly, the Epicurean Colotes uses the Stoic term to criticize Sceptics. Later, with the same purpose, Cicero will use the same term in his essay "On Academic Scepticism". Colotes tries to show that the practice of epoche is incompatible with life, since it interferes with action, for it is impossible to live without distinguishing between perceived objects. From that striving, Colotes' critics of the views of each philosopher separately flow as well. So, Democritus, in the first place, got it because he allegedly had claimed that each object could not exist without the other (Adv. Col. 4). In such a way Colotes interprets his understanding of atoms and emptiness by Democritus. Secondly, Colotes believes that Democritus threw «our life into confusion by saying that of objects each is no more of this quality than of that» (Adv. Col. 8) [12, p. 197]. That means, that objects are conditional (since everything is atoms and emptiness), and this conflicts with sensations, and therefore deprives a person of the opportunity to live. From the point of view of Colotes, Parmenides also deprived a person of this possibility, calling all things One (Adv. Col. 13).

Colotes accuses Empedocles of contradicting his teaching: stating that people are immortal (meaning the idea of soul relocation. - M.Sh.), nevertheless, he recognizes that people can suffer from wounds and diseases (Adv. Col. 12). Colotes is well acquainted with the writings of Plato, including the "Phaedo" and "Phaedrus". Interestingly, in the interpretation of Plutarch, Aristotle for Colotes is only a disciple of Plato. Plutarch criticizes Colotes for the fact that he, in his opinion, attributes to Aristotle and Peripatetics the 
support of the teachings of Plato. Colotes critically assesses the Platonic doctrine of ideas. Plutarch writes about this criticism: "But Plato says that it is idle to regard horses as being horses and men men. And where in Plato's writings did Colotes find this tucked away? I for one in reading them find that he everywhere regards man as man, horse as horse, and fire as fire ; indeed this is why he terms each of them an 'object of opinion"' (Adv. Col. 15) [12, p. 239]. According to Colotes' ironic statement, if Plato says that you cannot call a person a man, than Stilpo goes further, saying that it is impossible to do so. Colotes declares, that we cannot say anything different from the subject about it: "For how shall we live if we cannot call a man good or a man a general, but can only on one side call 'a man a man and on the other good good and general general, or if we cannot speak of ten thousand horse or a strong city, but only say that horsemen are horsemen and ten thousand ten thousand, and so with the rest?"(Adv. Col. 22) [12, p. 263]. Colotes mocks Stilpo's famous answer to Demetrius Poliorcetes, who, having captured Megara in $306 \mathrm{BC}$, ordered to return the plundered good to the philosopher. Stilpo stated that he had no losses: no one had taken away his education, and his knowledge and reason remained with him (DL II, 115).

According to Plutarch, Colotes most of all attacks Socrates, who is named Colotes a liar. Colotes mockingly inquired about Socrates: "How comes it that he puts his food in his mouth and not in his ear?" and "if he cares so little for the comfort of a cloak why wrap his cloak about himself and not put it around the column?" (Adv. Col. 2) [12, p. 195]. Attacking Socrates, Colotes seeks to get to Arcesilaus, who relied on Socratic dialectics in his teaching. Colotes interprets this method of Socrates as an essential vice, stating: "What you say to people in your conversations is one thing, and what you do is something completely different" (Adv. Col. 2) [11, p. 196]. In this, Colotes speaks in full accordance with the tradition of the Epicurean frankness (parrhesia), that is, the practice of frank speeches, which, as was considered in Epicureanism, could only support a person. Colotes ridicules the concept of epoche (doctrine of suspension of judgment), used by Arcesilaus, calling it "a bait for reckless young people": "But how comes it that the man who suspends judgement does not go dashing off to a mountain instead of to the bath, or why does he not get up and walk to the wall instead of the door when he wishes to go out to the market-place" (Adv. Col. 27) [12, p. 285]. Plutarch, commenting on this passage, remarks: "You ask this when you hold that the sense organs are accurate and sense images true? Why, because what appears to him to be a bath is not the mountain, but the bath, and what appears to him to be a door is not the wall, but the door, and so with everything else" (Adv. Col. 27) [12, p. 285]. Colotes ends his essay, directed against those who suspend the judgments, with the following words: "The men who appointed laws and customs and established the government of cities by kings and magistrates brought human life into a state of great security and peace and delivered it from tumults. If somebody should take all this away we shall live a life of beasts and anyone who chances upon another will all but devour him" (Adv. Col. 30) [12, p. 295].

Roman Epicureans were forced to defend their teachings from all sorts of accusations based on the erroneous interpretation of the views of Epicurus. The polemical sharpness of their writings was often directed not at traditional opponents - Academics or Stoics, but at "false" Epicureans, who misinterpreted the teachings of the founder of the Garden. A number of surviving fragments of Philodemus on Epicurus and Epicureans contain criticism of "false" Epicureans. He defended Garden from criticism and from all sorts of vulgarization, primarily emphasizing the behavior or opinion of Epicurus himself. He distinguished those 
who "babble" about Epicurus from those who followed his teachings, especially with regard to the mores that prevailed in school during the time of Epicurus (PHerc. 1005, col.15.3-13). On the other hand, he agreed with one of the opponents that among the Epicureans there were people who inadequately interpreted certain points of the Epicurus doctrine. Cicero, incidentally, pointed to this, drawing the line between educated and ignorant Epicureans and noting that the Epicureans had different points of view on the nature of the supreme good (De fin. I, 30-31), friendship (De fin. I, 66-70) and pleasure (De fin. I, 25). Philodemus considered in the work "On Epicurus" the history of Epicureanism from Epicurus to his teacher Zeno of Sidon (PHerc.1232, 1289). Philodemus' argument about the possibility of developing Epicurus's teaching was extremely important, since over the centuries researchers exaggerated the thesis about the dogmatism of the Epicurean philosophical tradition. Philodemus denied the view that those who "came to school after Hermarchus" did not make any changes to the teaching and practice. He wrote that he would rather believe that "all people are black, crooked and small in stature" than he admitted that all Epicureans "think and act in the same way" (PHerc. 1005, col.3.8-17) [13].

In the treatise "On Anger" by Philodemus, criticism of Peripatetics reinforced with an ironic reference to the point of view of the Stoics, pointing out that even Antipater of Tarsus did not believe that violent anger could protect a person from ferocious beasts or from death in battle, or use the well-known training as an example sword fighting, during which teachers constantly warn students to keep from anger. According to the Stoics, all emotions, including anger, are irrational excitations that should be suppressed. Plutarch, in his book "On Moral Virtue", writes that Chrysippus believes that "anger is blind" and that he "often prevents to see obvious things and interferes with correct comprehension", and "arising passions impede clear reasoning, distort the perception of things and forcefully oppose actions", and although man "is by nature a rational being, called upon to resort to reason and be guided by everything, we often turn away from him, giving way to another stronger impulse "(SVF III, 390) [12].

Philodemus argues on how anger harms the pursuit of philosophy, making it difficult to share joint research, hindering collective pursuits. He represents the point of view of Peripatetics (PHerc. 1005, col. 31-32) and criticizes it. Peripathetics did not consider that the sage should be completely deprived of feelings, including anger, and did not see the need to give up emotions. Philodemus writes that there is no need to argue that a soldier who does not submit to his superior causes the anger, but it must be admitted that all passion is evil, because it causes pain and causes harm. Therefore, one should distinguish between fair anger and empty anger, which should be avoided first of all (PHerc. 1005, col. 37-38). He points out that although anger is painful and therefore should be avoided, it is anger in human nature and cannot be completely avoided. Philodemus asks the question: if the wise man has suffered significant harm, will he be deeply wounded, will he be angry, and will he wish to punish the one who has harmed him? And he himself answers: the wise man should distance himself from this person as much as possible, but he will not be unbalanced (excited) by this circumstance, just as strong physical pain does not excite him. Naturally, the sage will not dream of revenge or punishing the offender as something pleasant: such an assessment of fair punishment is characteristic of a cruel person, and a sage cannot be cruel, as cruelty is the worst punishment for himself (PHerc. 1005, col. 41-42) [13]. Philodemus develops the idea of Epicurus that the sage cannot experience strong anger, and can only have "light" anger, while the gods do not feel anger at all. 
A peculiar rethinking of Plato's plots can be found in the poem "On the Nature of Things" by another Roman Epicurean, Lucretius. The third book of Lucretius' poem is polemical and is directed mainly against the arguments of the immortality of the soul set forth in the "Phaedo" (NR III, 440; 960-967; 1003-1010), but in the description of the "eternal world of the gods" in "Epicurus Praise" (NR III, 1-30) traced the influence of the Platonic notion of souls who "saw true being" in the "Phaedrus" (249a-d). Comparing the poem with "Timaeus" one may note multiple textual parallels.

Diogenes of Oenoanda, like other Epicureans, in his "stone book" setting forth the teachings of Epicurus, presented it in polemical form, criticizing other philosophers. He argued with Democritus and the Stoics about faith in prophetic dreams [14, fr. 9]; criticized the teaching of metempsychosis of Pythagoras and Empedocles [14, fr. 40-42]; exposed the mantic and oracles. Like Philodemus, Diogenes defended the Epicureans from the charge of godlessness, saying: "And they vehemently denounce the most pious people as atheistic. And in fact it will become evident that it is not we who deny the gods, but others. Thus Diagoras of Melos, with certain others who closely followed his theory, categorically asserted that gods do not exist and vigorously attacked all those who thought otherwise. Protagoras of Abdera in effect put forward the same view as Diagoras, but expressed it differently to avoid its excessive audacity. For he said that he did not know whether gods exist, which is the same as saying that he knew that they do not exist" [14, fr. 16].

Diogenes criticized the views of the Pythagoreans, Platonists and the Stoics on the nature of the soul. He wrote that [the soul cannot survive separation from the body, "since it is necessary to understand that it too is a part. By itself the soul cannot ever either exist (even though Plato and the Stoics talk a great deal of nonsense on the subject) or experience movement, just as the body does] not possess sensation when the soul is released from it" [14, fr. 38]. He called: "And let us not say that the soul transmigrated and did not perish, as the Orphics, and not only Pythagoras, crazily suppose" [14, fr. 404]. Epicurus said that the mental properties of a person are inseparable from the body, therefore "one cannot think of anything else incorporeal except for emptiness... Therefore, they say that the soul is incorporeal, they say nonsense" (DL, X, 67) [4, p. 599].

Concluding we may say that as we know, the most important principle of the Epicurean doctrine is the healing of the soul by philosophy. Just as you need to find the right medicine for treating bodily diseases, you need to find the right effect on people's souls. According to the Epicureans, the frank speech is a means of treating moral vices. Just as an experienced doctor chooses a medicine, guided by the detected symptoms of the disease, an experienced soul healer applies his technique. And if Epicurus himself, in expounding his teaching, was repelled from opposing points of view, resorted mainly to implicit criticism of his opponents, most often without naming them, and often used the same terms, giving them a different content. His writings, clearly explaining the terms used, had a certain preaching pathos, aimed not only for the enlightenment and correction of morals, but also indicating the ways of this correction. His followers, continuing the controversy with the Academics and the Stoics, more frankly expressed their indignation at the "falsely understood epicureanism" or erroneous points of view. In their writings, satirical techniques and angry denunciations were often used to criticize opponents. 


\section{References}

1. Solmsen, F., (1951), "Epicurus and Cosmological Heresies", American Journal of Philology, vol. 72, pp. 1-23.

2. Solmsen, F., (1953) Epicurus on the Growth and the Decline of the Cosmos, American Journal of Philology, vol. 74, pp. 34-51.

3. Cicero (1997), The Nature of Gods, trans. by Walsh, P. G., Clarendon Press, Oxford, 234 p.

4. Diogenes Laertius, (1925), The Life of Eminent Philosophers, with an English trans. by Hicks, R. D., in 2 vols., vol. II, W. Heinemann, London, 728 p.

5. Feuerbach, L., (1890), The Essence of Christianity, trans. from the second German ed., Kegan Paul, London.

6. Crönert, W. (1906), Kolotes und Menedemos. Texte und Untersuchungen zur Philosophen- und Literaturgeschichte, E. Avenarius, Leipzig, 198 p. 215.

7. Glidden, D. K. (1985), "Epicurean Prolepsis", Oxford Studies in Ancient Philosophy, vol. III, pp. 175-

8. Longo, A. F., (1988), Ermarco. Frammenti, Bibliopolis, Naples (La Scuola di Epicuro, vol. 6), 196 p.

9. Stahl, W.H., (1990), Commentary on the Dream of Scipio by Macrobius, Columbia University Press, New York, $278 \mathrm{p}$.

10. Armisen-Marchetti, M. (2001), Macrobe. Commentaire au Songe de Scipion, Livre I. Texte ét., trad. et comm., ser. Collection des Universtés de France, Les Belles Lettres, Paris, CVII + 339 p.

11. Kechagia, E. (2011), Plutarch Against Colotes: A Lesson in History of Philosophy, Oxford University Press, Oxford, xvii+359 p.

12. Putarchus, (1967), Moralia, vol. XIV, with Eng. trans. by Einarson, B. and De Lacy, P., Harvard University Press, Cambridge, $480 \mathrm{p}$.

13. Filodemo, (1988), Agli Amici di Scuola, ed. A. Angeli, Bibliopolis, Naples. 353 p.

14. Diogenes of Oinoanda, (1993), The Epicurean Inscription, trans. and notes by Smith, M. F., Bibliopolis, Naples, 660 p.

Received: February 28, 2019

Accepted: June 13, 2019

Author's information:

Marianna M.Shakhnovich - Dr. Sci. in Philosophy, Professor; m.shakhnovich@spbu.ru

\section{Полемическая практика в древнем эпикуреизме}

\section{М. М. Шахнович}

Санкт-Петербургский государственный университет,

Российская Федерация, 199034, Санкт-Петербург, Университетская наб., 7-9

Для цитирования: Shakhnovich M.M. The polemical practice in ancient Epicureanism // Bестник Санкт-Петербургского университета. Философия и конфликтология. 2019. Т. 35. Вып. 3. C. 461-471. https://doi.org/10.21638/spbu17.2019.306

В статье исследуются методы презентации греческими и римскими эпикурейцами своего философского учения, показывается, что для древнего, среднего и римского Сада характерным способом представления собственных воззрений была полемика с представителями других философских школ. Полемическая практика, в которой основные положения эпикуреизма излагались через критику иных философских систем, прежде всего академиков и стоиков, рассматривалась не только как предпочтительный способ презентации собственной доктрины, но и как наиболее удобный риторический прием, имевший, в том числе и дидактическое значение. Основатель школы Эпикур нередко вводил в свои тексты термины, используемые в других фило- 
софских школах, придавая им иное, нередко противоположное, содержание. Излагая свое учение в трактате «О природе» или в письмах к своим последователям, Эпикур отталкивался от мнений Демокрита, Платона, стоиков, однако прибегал в основном к имплицитной критике своих оппонентов, часто не называя их по имени. Его ближайшие ученики и поздние последователи - Метродор, Гермарх, Колот, Филодем, Лукреций, Диоген из Эноанды, - продолжая полемику с академиками и стоиками, более откровенно высказывали свое негодование по поводу «ложно понятого эпикуреизма» или ошибочных мнений. В их сочинениях нередко использовались в критике оппонентов сатирические приемы и гневные обличения. Основное внимание в статье уделяется полемике Эпикура с Платоном; интерпретации понятия «предвосхищение» у Эпикура и стоиков; полемическим приемам Колота и использованию им принципа "воздержания от суждения», почерпнутого у стоиков, для критики академиков. Кроме того, в статье анализируются риторические приемы Филодема, который полагал, что прямодушие является не только наилучшим способом врачевания души, но и методом философской полемики.

Ключевые слова: Эпикур, эпикуреизм, Колот, Филодем, римский эпикуреизм, стоицизм, скептицизм, полемический прием.

Статья поступила в редакцию 28 февраля 2019 г;; рекомендована в печать 13 июня 2019 г.

Контактная информация:

Шахнович Марианна Михайловна - д-р филос. наук, проф.; m.shakhnovich@spbu.ru 